\title{
Doxycycline for osteoarthritis of the knee or hip (Review)
}

\author{
Nüesch E, Rutjes AWS, Trelle S, Reichenbach S, Jüni P
}

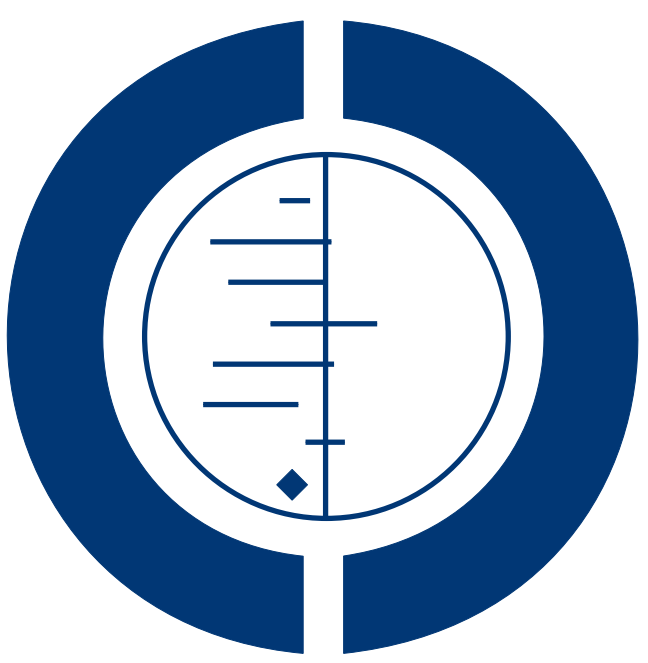

\section{THE COCHRANE COLLABORATION $^{\circledR}$}

This is a reprint of a Cochrane review, prepared and maintained by The Cochrane Collaboration and published in The Cochrane Library 2009, Issue 4

http://www.thecochranelibrary.com

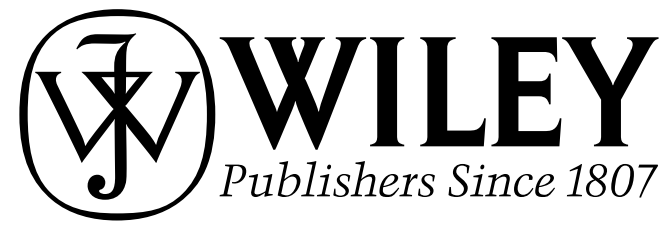

Doxycycline for osteoarthritis of the knee or hip (Review)

Copyright (@) 2009 The Cochrane Collaboration. Published by John Wiley \& Sons, Ltd. 
TABLE OF CONTENTS

HEADER . . . . . . . . . . . . . . . . . . . . . . . . . . . . . . . . . . . . . . . 1

ABSTRACT . . . . . . . . . . . . . . . . . . . . . . . . . . . . . . . . . . . . . . . . . . 1

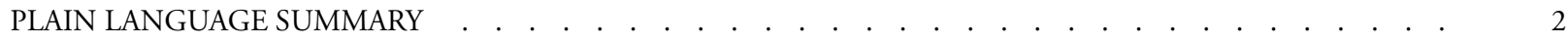

SUMMARY OF FINDINGS FOR THE MAIN COMPARISON . . . . . . . . . . . . . . . . . . . . . . . 3

BACKGROUND . . . . . . . . . . . . . . . . . . . . . . . . . . . . . . . . . . . . 6

OBJECTIVES . . . . . . . . . . . . . . . . . . . . . . . . . . . . . . . . . . . . . 6

METHODS . . . . . . . . . . . . . . . . . . . . . . . . . . . . . . . . . . . . . . 6

Figure 1. . . . . . . . . . . . . . . . . . . . . . . . . . . . . . . . . . . . . . 8

RESULTS . . . . . . . . . . . . . . . . . . . . . . . . . . . . . . . . . . . 9

Figure 2. . . . . . . . . . . . . . . . . . . . . . . . . . . . . . . . . . . . . . 11

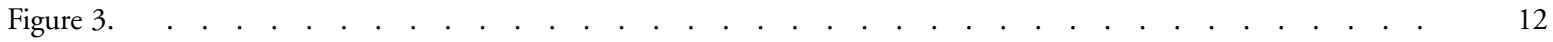

Figure $4 . \quad$. . . . . . . . . . . . . . . . . . . . . . . . . . . . . . . . . . . . . 12

Figure 5. . . . . . . . . . . . . . . . . . . . . . . . . . . . . . . . . . . . 13

Figure 6. . . . . . . . . . . . . . . . . . . . . . . . . . . . . . . . . . . . . . 14

Figure $7 . \quad$. . . . . . . . . . . . . . . . . . . . . . . . . . . . . . . . . . . . . 14

DISCUSSION . . . . . . . . . . . . . . . . . . . . . . . . . . . . . . . . . . . . . . . . . . . . . .

AUTHORS' CONCLUSIONS . . . . . . . . . . . . . . . . . . . . . . . . . . . . . . . 15

ACKNOWLEDGEMENTS . . . . . . . . . . . . . . . . . . . . . . . . . . . . . . . . . . . . . . 15

REFERENCES . . . . . . . . . . . . . . . . . . . . . . . . . . . . . . . . . . . . . 16

CHARACTERISTICS OF STUDIES . . . . . . . . . . . . . . . . . . . . . . . . . . . . . . . . . . . 17

DATA AND ANALYSES . . . . . . . . . . . . . . . . . . . . . . . . . . . . . . . . . . . . . . . . 20

Analysis 1.1. Comparison 1 Doxycycline versus placebo, Outcome 1 Pain. . . . . . . . . . . . . . . . 20

Analysis 1.2. Comparison 1 Doxycycline versus placebo, Outcome 2 Physical function. . . . . . . . . . . . . . 21

Analysis 1.3. Comparison 1 Doxycycline versus placebo, Outcome 3 Minimum joint space width. . . . . . . . . . $\quad 21$

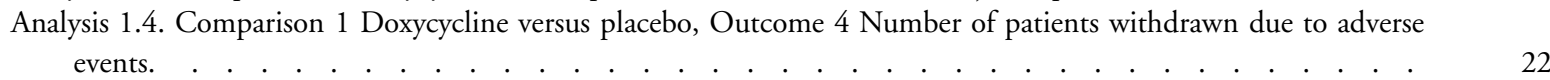

Analysis 1.5. Comparison 1 Doxycycline versus placebo, Outcome 5 Number of patients experiencing any serious adverse events. . . . . . . . . . . . . . . . . . . . . . . . . . . 22

APPENDICES . . . . . . . . . . . . . . . . . . . . . . . . . . . . . . . . . . . . . . 22

WHAT'S NEW . . . . . . . . . . . . . . . . . . . . . . . . . . . . . . . . . . . . . $\quad 25$

HISTORY . . . . . . . . . . . . . . . . . . . . . . . . . . . . . . . . . . . . . . . 25

CONTRIBUTIONS OF AUTHORS . . . . . . . . . . . . . . . . . . . . . . . . . . . . . . . . . . . . . . 26

DECLARATIONS OF INTEREST . . . . . . . . . . . . . . . . . . . . . . . . . . . . . . . . . . . . . . . 26

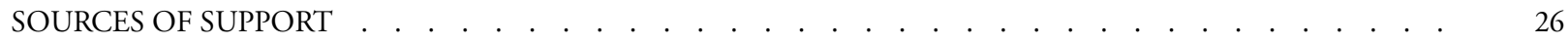

DIFFERENCES BETWEEN PROTOCOL AND REVIEW

Doxycycline for osteoarthritis of the knee or hip (Review)

Copyright ( 2009 The Cochrane Collaboration. Published by John Wiley \& Sons, Ltd. 


\title{
[Intervention Review]
}

\section{Doxycycline for osteoarthritis of the knee or hip}

\author{
Eveline Nüesch ${ }^{1}$, Anne WS Rutjes ${ }^{1}$, Sven Trelle ${ }^{2}$, Stephan Reichenbach ${ }^{3}$, Peter Jüni ${ }^{1}$
}

${ }^{1}$ Division of Clinical Epidemiology and Biostatistics, Institute of Social and Preventive Medicine, University of Bern, Bern, Switzerland. ${ }^{2}$ Institute of Social and Preventive Medicine, University of Bern, Bern, Switzerland. ${ }^{3}$ Department for Rheumatology, Clinical Immunology, and Allergology, University Hospital, Bern, Switzerland

Contact address: Eveline Nüesch, Division of Clinical Epidemiology and Biostatistics, Institute of Social and Preventive Medicine, University of Bern, Finkenhubelweg 11, Bern, 3012, Switzerland. enueesch@ispm.unibe.ch. (Editorial group: Cochrane Musculoskeletal Group.)

Cochrane Database of Systematic Reviews, Issue 4, 2009 (Status in this issue: New)

Copyright (C) 2009 The Cochrane Collaboration. Published by John Wiley \& Sons, Ltd.

DOI: 10.1002/14651858.CD007323.pub2

This version first published online: 7 October 2009 in Issue 4, 2009.

Last assessed as up-to-date: 10 January 2009. (Help document - Dates and Statuses explained)

This record should be cited as: Nüesch E, Rutjes AWS, Trelle S, Reichenbach S, Jüni P. Doxycycline for osteoarthritis of the knee or hip. Cochrane Database of Systematic Reviews 2009, Issue 4. Art. No.: CD007323. DOI: 10.1002/14651858.CD007323.pub2.

\begin{abstract}
A B S T R A C T
Background

Osteoarthritis is a chronic joint disease that involves degeneration of articular cartilage. Pre-clinical data suggest that doxycycline might act as a disease-modifying agent for the treatment of osteoarthritis, with the potential to slow cartilage degeneration.
\end{abstract}

\section{Objectives}

To examine the effects of doxycycline compared with placebo or no intervention on pain and function in patients with osteoarthritis of the hip or knee.

\section{Search strategy}

We searched CENTRAL (The Cochrane Library 2008, issue 3), MEDLINE, EMBASE and CINAHL up to 28 July 2008, checked conference proceedings, reference lists, and contacted authors.

\section{Selection criteria}

We included studies if they were randomised or quasi-randomised controlled trials that compared doxycycline at any dosage and any formulation with placebo or no intervention in patients with osteoarthritis of the knee or hip.

\section{Data collection and analysis}

We extracted data in duplicate. We contacted investigators to obtain missing outcome information. We calculated differences in means at follow-up between experimental and control groups for continuous outcomes and risk ratios for binary outcomes.

\section{Main results}

We found one randomised controlled trial that compared doxycycline with placebo in 431 obese women. After 30 months of treatment, clinical outcomes were similar between the two treatment groups, with a mean difference of $-0.20 \mathrm{~cm}(95 \%$ confidence interval (CI) -0.77 to $0.37 \mathrm{~cm}$ ) on a visual analogue scale from 0 to $10 \mathrm{~cm}$ for pain and -1.10 units ( $95 \% \mathrm{CI}-3.86$ to 1.66 ) for function on the WOMAC disability subscale, which ranges from 17 to 85 . These differences correspond to clinically irrelevant effect sizes of -0.08 and -0.09 standard deviation units for pain and function, respectively. The difference in changes in minimum joint space narrowing was in favour of doxycycline $(-0.15 \mathrm{~mm}, 95 \%$ CI -0.28 to $-0.02 \mathrm{~mm})$, which corresponds to a small effect size of -0.23 standard deviation 
units. More patients withdrew from the doxycycline group compared with placebo due to adverse events (risk ratio $1.69,95 \%$ CI 1.03 to 2.75 ).

\section{Authors' conclusions}

The symptomatic benefit of doxycycline is minimal to non-existent. The small benefit in terms of joint space narrowing is of questionable clinical relevance and outweighed by safety problems. Doxycycline should not be recommended for the treatment of osteoarthritis of the knee or hip.

\section{PLAIN LANGUAGESUMMARY}

\section{Doxycycline for osteoarthritis}

This summary of a Cochrane review presents what we know from research about the effect of doxycycline on osteoarthritis.

\section{The review shows that in people with osteoarthritis:}

- Doxycycline probably will not improve pain or physical function.

- Doxycycline probably causes side effects. We often do not have precise information about side effects and complications. This is particularly true for rare but serious side effects.

\section{What is osteoarthritis and what is doxycycline?}

Osteoarthritis (OA) is a disease of the joints, such as your knee or hip. When the joint loses cartilage, the bone grows to try and repair the damage. Instead of making things better, however, the bone grows abnormally and makes things worse. For example, the bone can become misshapen and make the joint painful and unstable. This can affect your physical function or ability to use your knee.

Doxycycline is a type of antibiotic that seems to stop the process of damage to the joints. It is taken in pill form.

\section{Best estimate of what happens to people with osteoarthritis who take doxycycline:}

\section{Pain}

- People with doxycycline and people with placebo are equally likely to respond to treatment (difference of $0 \%$ ).

- People who took doxycycline rated their pain to be 2 on a scale of 0 (no pain) to 10 (extreme pain) after 30 months.

- People who took a fake medication (placebo) also rated their pain to be about 2 on a scale of 0 (no pain) to 10 (extreme pain) after 30 months.

\section{Physical function}

- People with doxycycline and people with placebo are equally likely to respond to treatment (difference of $0 \%$ ).

- People who took doxycycline rated their physical function to be about 36 on a scale of 17 (no disability) to 85 (extreme disability) after 30 months.

- People who took a fake medication rated their physical function to be about 37 on a scale of 17 (no disability) to 85 (extreme disability) after 30 months. 


\section{Side effects}

- 7 more people who took doxycycline withdrew or dropped out from the trial because of side effects (absolute difference of 7\%).

- 17 people out of 100 who took doxycycline withdrew or dropped out from the trial because of side effects (17\%).

- 10 people out of 100 who used a fake medication withdrew or dropped out from the trial because of side effects (10\%).

\section{Serious harms}

- There was no difference in the number of people who experienced serious harms (difference of $0 \%$ ). This could be the result of chance.

- 14 people out of 100 who took doxycycline experienced serious harms (14\%)

- 14 people out of 100 who used a fake medication experienced serious harms (14\%). 
SUMMARY OF FINDINGS FOR THE MAIN COMPARISON [Explanation]

Doxycycline compared with placebo for osteoarthritis of the knee or hip

Patient or population: Patients with osteoarthritis of the knee or hip

Settings: Clinical Research Centres

Intervention: Doxycycline

Comparison: Placebo

\begin{tabular}{|c|c|c|c|c|c|c|}
\hline \multirow[t]{3}{*}{ Outcomes } & \multicolumn{2}{|c|}{ Illustrative comparative risks* $(95 \%$ Cl) } & \multirow{3}{*}{$\begin{array}{l}\text { Relative effect } \\
(95 \% \mathrm{CI})\end{array}$} & \multirow{3}{*}{$\begin{array}{l}\text { No of Participants } \\
\text { (studies) }\end{array}$} & \multirow{3}{*}{$\begin{array}{l}\text { Quality of the evidence } \\
\text { (GRADE) }\end{array}$} & \multirow[t]{3}{*}{ Comments } \\
\hline & Assumed risk ${ }^{1}$ & Corresponding risk & & & & \\
\hline & Placebo & Doxycycline & & & & \\
\hline $\begin{array}{l}\text { Pain } \\
10 \mathrm{~cm} \text { VAS scale } \\
\text { (follow-up: } 30 \text { months) }\end{array}$ & $\begin{array}{l}2.2 \mathrm{~cm} \text { pain } \\
\text { on } 10 \mathrm{~cm} \text { VAS }\end{array}$ & $\begin{array}{l}2.0 \mathrm{~cm} \text { pain } \\
(\Delta-0.2 \mathrm{~cm},-0.8 \text { to }+0.4 \\
\mathrm{cm})\end{array}$ & & $\begin{array}{l}307 \\
(1)\end{array}$ & $\begin{array}{l}++00 \\
\operatorname{low}^{2}\end{array}$ & $\begin{array}{l}\text { Little evidence of beneficial } \\
\text { effect (NNT: not statistically } \\
\text { significant) }\end{array}$ \\
\hline $\begin{array}{l}\text { Function } \\
\text { WOMAC function (range } 17 \\
\text { to } 85 \text { ) } \\
\text { (follow-up: } 30 \text { months) }\end{array}$ & $\begin{array}{l}37.4 \text { units on WOMAC } \\
\text { (range } 17 \text { to } 85 \text { ) }\end{array}$ & $\begin{array}{l}36.3 \text { units on WOMAC } \\
(\Delta-1.1,-3.9 \text { to }+1.7)\end{array}$ & & $\begin{array}{l}307 \\
(1)\end{array}$ & $\begin{array}{l}++00 \\
\operatorname{low}^{2}\end{array}$ & $\begin{array}{l}\text { Little evidence of beneficial } \\
\text { effect (NNT: not statistically } \\
\text { significant) }\end{array}$ \\
\hline $\begin{array}{l}\text { Minimum joint space } \\
\text { width } \\
\text { (follow-up: } 30 \text { months) }\end{array}$ & $-45 \mathrm{~mm}$ change & $\begin{array}{l}\text {-30 mm change } \\
(\Delta 15 \mathrm{~mm}, 2 \text { to } 28 \mathrm{~mm})\end{array}$ & & $\begin{array}{l}361 \\
(1)\end{array}$ & $\begin{array}{l}+++0 \\
\text { moderate }^{3}\end{array}$ & $\begin{array}{l}\text { No reasonable assumption } \\
\text { could be made for the cal- } \\
\text { culation of NNT }\end{array}$ \\
\hline $\begin{array}{l}\text { Number of patients with- } \\
\text { drawn due to adverse } \\
\text { events } \\
\text { (follow-up: } 30 \text { months) }\end{array}$ & 103 per 1000 & $\begin{array}{l}174 \text { per } 1000 \\
(106 \text { to } 283)\end{array}$ & RR 1.69 (1.03 to 2.75$)$ & $\begin{array}{l}431 \\
(1)\end{array}$ & $\begin{array}{l}+++0 \\
\text { moderate }^{3}\end{array}$ & NNH: 14 (95\% Cl 6 to 324) \\
\hline $\begin{array}{l}\text { Number of patients expe- } \\
\text { riencing any serious ad- } \\
\text { verse event } \\
\text { (follow-up: } 30 \text { months) }\end{array}$ & 136 per 1000 & $\begin{array}{l}141 \text { per } 1000 \\
\text { (88 to 227) }\end{array}$ & RR 1.04 (0.65 to 1.67 ) & $\begin{array}{l}431 \\
(1)\end{array}$ & $\begin{array}{l}++00 \\
\text { low }^{4}\end{array}$ & $\begin{array}{l}\text { Little evidence of harmful } \\
\text { effect (NNH: not statistically } \\
\text { significant) }\end{array}$ \\
\hline
\end{tabular}

(follow-up: 30 months) 
*The basis for the assumed risk (e.g. the median control group risk across studies) is provided in footnotes. The corresponding risk (and its $95 \%$ confidence interval) is based on the assumed risk in the comparison group and the relative effect of the intervention (and its $95 \% \mathrm{Cl}$ ).

Cl: confidence interval; RR: risk ratio; GRADE: GRADE Working Group grades of evidence (see explanations); NNT: number needed to treat; NNH: number needed to harm

GRADE Working Group grades of evidence

High quality $(++++)$ : Further research is very unlikely to change our confidence in the estimate of effect.

Moderate quality $(+++0)$ : Further research is likely to have an important impact on our confidence in the estimate of effect and may

change the estimate.

Low quality $(++\mathbf{0 0})$ : Further research is very likely to have an important impact on our confidence in the estimate of effect and is likely

to change the estimate.

Very low quality $(+\mathbf{0 0 0})$ : We are very uncertain about the estimate.

${ }^{1}$ Scores for efficacy outcomes and risks for safety outcomes from the placebo group in the trial.

${ }^{2}$ Downgraded (2 levels) because the effect was estimated from a single trial, confidence intervals were wide and crossed no difference,

and the analyses were not done according to the intention-to-treat principle.

${ }^{3}$ Downgraded ( 1 level) because the effect was estimated from a single trial.

${ }^{4}$ Downgraded (2 levels) because the effect was estimated from a single trial, confidence intervals were wide and crossed no difference. 


\section{B A C K G R O U N D}

Osteoarthritis is a chronic joint disease that involves degeneration of the articular cartilage. Doxycycline is a tetracycline antibiotic which has been shown to induce inhibition of cartilage matrix metallo-proteinases (MMPs) and to slow down the progression of structural damage to the affected joint (Shlopov 1999; Smith 1996). Doxycycline was therefore suggested as a disease-modifying agent for the treatment of osteoarthritis. Treatment with oral doxycycline may slow down the rate of joint space narrowing, which is used as a surrogate measure for cartilage loss of the knee in patients with knee osteoarthritis (Brandt 2005). However, treatment benefits of putative chondro-protective disease-modifying agents are still controversial. Chondroitin and glucosamine are other potentially structure-modifying pharmacological substances that are widely used to reduce the symptoms of osteoarthritis of the hip or knee. Recently published meta-analyses, however, have questioned their effectiveness because of large heterogeneity between studies and biases introduced by industry sponsored, methodologically weak and small trials (Reichenbach 2007; Vlad 2007). As a tetracycline antibiotic, doxycycline interferes with various biological pathways and has effects on tissues other than cartilage ( Rubin 2000). Safety concerns about the long-term use of doxycycline have also been expressed, especially in elderly patients with co-morbid conditions (Dieppe 2005).

\section{O B JE C T IVES}

We set out to compare doxycycline with placebo or no specific intervention in patients with knee or hip osteoarthritis in terms of effects on pain, function and safety outcomes.

\section{METHODS}

\section{Criteria for considering studies for this review}

\section{Types of studies}

Randomised or quasi-randomised controlled trials with a control group receiving placebo or no intervention.

\section{Types of participants}

Studies including at least $75 \%$ of patients with clinically and/or radiologically confirmed osteoarthritis of the knee or hip.

\section{Types of interventions}

Trials investigating doxycycline at any dosage and in any formulation. Eligible control interventions were placebo or no intervention.

\section{Types of outcome measures}

\section{Primary outcomes}

Main outcomes were pain and function, as currently recommended for osteoarthritis trials (Altman 1996; Pham 2004). If data on more than one pain scale were provided for a trial, we referred to a previously described hierarchy of pain-related outcomes (Juni 2006; Reichenbach 2007) and extracted data on the pain scale that was highest on this list.

1. Global pain

2. Pain on walking

3. WOMAC osteoarthritis index pain subscore

4. Composite pain scores other than WOMAC

5. Pain on activities other than walking

6. Rest pain or pain during the night

7. WOMAC global algofunctional score

8. Lequesne osteoarthritis index global score

9. Other algofunctional scale

10. Patient's global assessment

11. Physician's global assessment

If data on more than one function scale were provided for a trial, we extracted data according to the hierarchy presented below.

1. Global disability score

2. Walking disability

3. WOMAC disability subscore

4. Composite disability scores other than WOMAC

5. Disability other than walking

6. WOMAC global scale

7. Lequesne osteoarthritis index global score

8. Other algofunctional scale

9. Patient's global assessment

10. Physician's global assessment

If pain or function outcomes were reported at several time points, we extracted the measure at the end of the trial or at a maximum of three months after termination of therapy, whichever came first.

\section{Secondary outcomes}

Secondary outcomes were minimum and mean radiographic joint space width, the number of patients experiencing any adverse event, patients who withdrew because of adverse events, and patients experiencing any serious adverse events. We defined serious adverse events as events resulting in in-patient hospitalisation, prolongation of hospitalisation, persistent or significant disability, congenital abnormality/birth defect of offspring, life-threatening events or death.

\section{Search methods for identification of studies}

\section{Electronic searches}

We searched the Cochrane Central Register of Controlled Trials (CENTRAL) (The Cochrane Library 2008, issue 3), MEDLINE (1966 to July 2008) and EMBASE (1975 to July 2008) through the Ovid platform (www.ovid.com), and CINAHL (1937 to July 2008) through EBSCOhost, using truncated variations of preparation names, including brand names, combined with truncated 
variations of terms related to osteoarthritis, all as text words. We applied a validated methodological filter for controlled clinical trials (Dickersin 1994). The specific search algorithms are displayed in Appendix 1 for MEDLINE, EMBASE and CINAHL, and in Appendix 2 for CENTRAL.

\section{Searching other sources}

We manually searched conference proceedings, used Science Citation Index to retrieve reports citing relevant articles, contacted content experts and trialists, and screened reference lists of all obtained articles, including related reviews. Finally, we searched several clinical trial registries ( www.clinicaltrials.gov, www.controlledtrials.com, www.actr.org.au and www.umin.ac.jp/ ctr) to identify ongoing trials. The last update of the search was performed on 28 July 2008.

\section{Data collection and analysis}

\section{Selection of studies}

Two review authors (EN and AR) independently evaluated all yielded titles and abstracts for eligibility (see Figure 1). We resolved disagreements by consensus. No language restrictions were applied. In case of multiple reports relating to the same trial, we considered all reports. 
Figure I. Flow chart

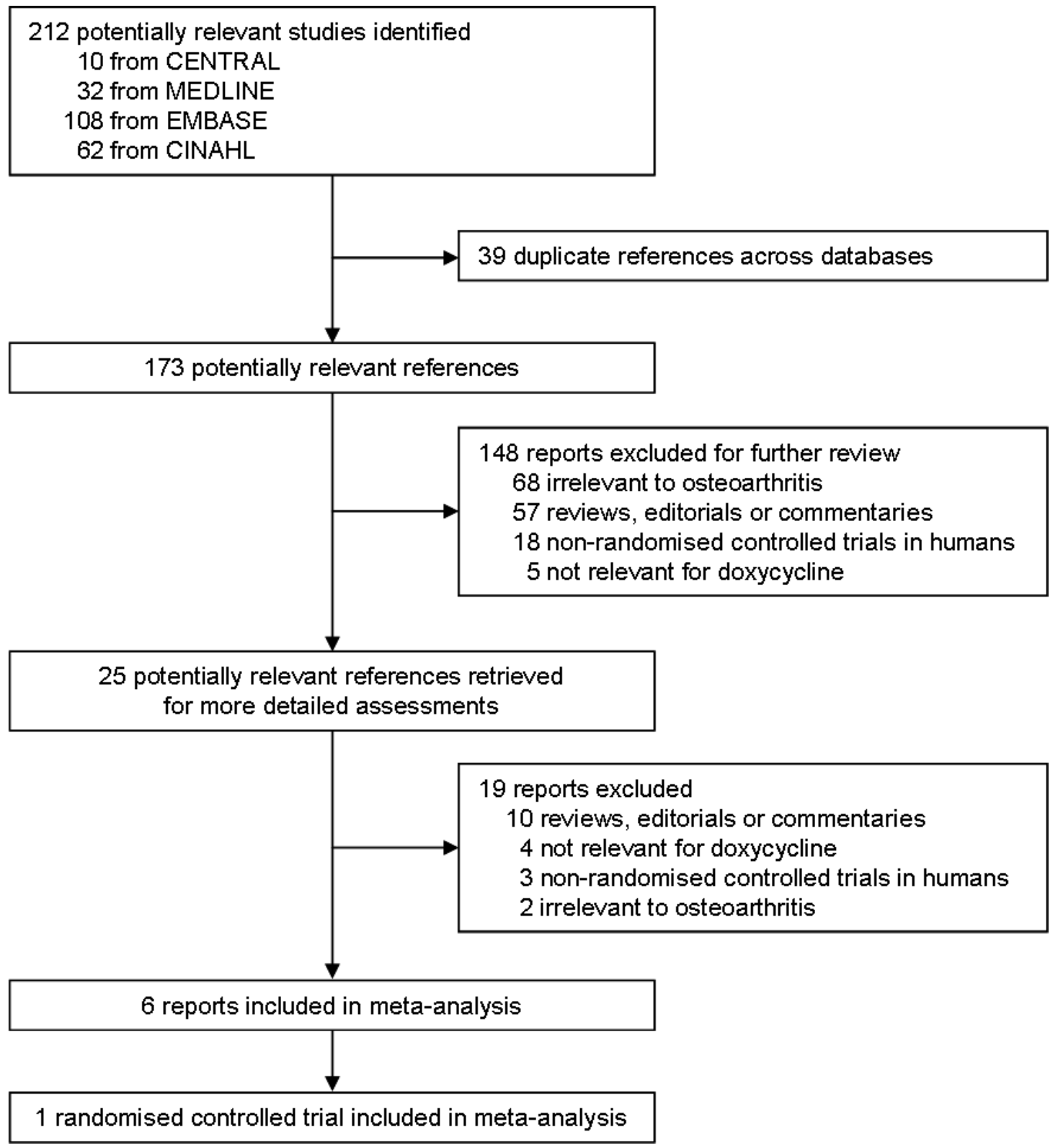




\section{Data extraction and management}

Two review authors (EN and AR) extracted trial information independently using a standardised, piloted data extraction form accompanied by a codebook. We resolved disagreements by discussion or by involvement of a third review author (SR or PJ). We extracted generic and trade names of the experimental intervention, the type of control used, dosage, frequency and duration of treatment, patient characteristics (average age, gender, mean duration of symptoms, type of joints affected), type of pain- and function-related outcome extracted, trial design, trial size, duration of follow-up, type and source of financial support, and publication status from trial reports. When necessary, we approximated means and measures of dispersion from figures in the reports. For crossover trials, we extracted data from the first period only because of possible carry-over effects. Whenever possible, we used results from an intention-to-treat analysis. If effect sizes could not be calculated, we contacted the authors for additional data.

\section{Assessment of risk of bias in included studies}

Two review authors (EN and AR) independently assessed the adequacy of randomisation, blinding and analyses (Juni 2001). We resolved disagreements by consensus or discussion with a third review author (SR or PJ). We assessed two components of randomisation: generation of allocation sequences and concealment of allocation. We considered generation of sequences adequate if it resulted in an unpredictable allocation schedule; mechanisms considered adequate included random-number tables, computergenerated random numbers, minimisation, coin tossing, shuffling cards and drawing lots. We considered concealment of allocation adequate if the investigators responsible for patient inclusion were unable to suspect before allocation which treatment was next; methods considered adequate include central randomisation, pharmacy controlled randomisation using identical prenumbered containers, and sequentially numbered, sealed, opaque envelopes. We considered blinding of the patients adequate if experimental and control preparations were explicitly described as indistinguishable or if a double-dummy technique was used. We considered blinding of therapists and outcome assessors adequate if it was explicitly mentioned in the report that they were unaware of the assigned treatment. If pain outcomes were patient-administered, however, we considered patients to be the outcome assessors and rated blinding of outcome assessors adequate if patients were deemed adequately blinded as described above. We considered analyses adequate if all randomised patients were included in the analysis (intention-to-treat principle). Finally, we used GRADE to describe the quality of the overall body of evidence (Guyatt 2008; Higgins 2008), defined as the extent of confidence in the estimated treatment benefits and harms.

\section{Data synthesis}

We summarised continuous outcomes using differences in means at the end of treatment across treatment groups. If some of the required data were unavailable, we used approximations as previ- ously described (Reichenbach 2007). We also expressed continuous outcomes as effect sizes in standard deviation units, with the differences in mean values at the end of follow-up across treatment groups divided by the pooled standard deviation. An effect size of -0.20 standard deviation units can be considered a small difference between experimental and control groups, a SMD of -0.50 a moderate difference, and -0.80 a large difference (Cohen 1988; Juni 2006). We expressed binary outcomes as risk ratios (RR). We performed analyses in RevMan version 5 (RevMan 2008). All P values are two-sided.

\section{RE S U T S}

\section{Description of studies}

See: Characteristics of included studies; Characteristics of excluded studies.

We retrieved 212 potentially relevant reports from our electronic searches (Figure 1). We excluded a randomised placebo-controlled trial of doxycycline in seronegative arthritis (Smieja 2001) and an animal study that assessed the effects of oral doxycycline in dogs ( Brandt 1995). Six reports, describing one randomised controlled trial, met our inclusion criteria (Brandt 2005). We did not find any additional completed trials in conference proceedings, nor did we identify relevant ongoing trials in trial registers. The included trial was a multicentre, placebo-controlled trial in 431 obese women with radiologically confirmed osteoarthritis of the knee. After a single-blind placebo run-in of four weeks duration, which was designed to allow the exclusion of patients unlikely to be compliant with trial procedures, patients were randomly allocated to receive $100 \mathrm{mg}$ doxycycline or placebo twice a day for 30 months. Patients were permitted to take any pain medication throughout the trial.

\section{Risk of bias in included studies}

An overview of the methodological characteristics of the included trial is presented in Figure 2. The trial was described as randomised in blocks of six, although mechanisms to generate blocks of random sequences and methods used to conceal allocation to treatments were not specified. The trial was reported as double-blind after a single-blind run-in period. We deemed blinding of patients adequate in view of the use of a matching placebo. Patients were explicitly described as blinded, whereas blinding of treating physicians was not explicitly described. Analyses of clinical outcomes, such as pain and function, were based on 307 patients who completed the 30-month treatment period as mandated in the protocol (Brandt 2005). Analyses of radiological outcomes included all 361 patients who returned for their radiographic follow-up irrespective of whether they discontinued the study drug. Safety analyses included all 431 randomised patients according to the intention-totreat principle. The primary outcome of the trial was joint space 
narrowing on the semiflexed AP view in the tibiofemoral joint ( Buckland-Wright 1995). Measurements were done manually, according to the method of Lequesne (Lequesne 1995), using the points of a screw-adjustable compass and a graduated magnifying lens. Measurements were made by an observer who was blinded to the treatment group assignment of the subject. The intra- and inter-reader reproducibilities of repeated measurements of joint space width in a random sample of 30 radiographs (on which all identifying information was masked) were excellent (intraclass correlation coefficients of 0.99 and 0.96 , respectively). Assessors determining the joint space width were not blinded to the sequence of the radiographs. No sample size calculation was described. The trial was supported in part by the National Institute of Health (NIH); no commercial funding was reported. For the effectiveness outcomes, we classified the quality of the evidence (Guyatt 2008) as low to moderate, because only a single trial was available, estimates were not derived from intention-to-treat analyses, and were imprecise for pain and function (see 'Summary of findings for the main comparison'). For withdrawals due to adverse events and serious adverse event outcomes, we classified the quality of the evidence (Guyatt 2008) as low to moderate in view of a single available trial and an imprecise estimate for serious adverse events (see 'Summary of findings for the main comparison'). 
Figure 2. Methodological characteristics and source of funding of the included trial. (+) indicates low risk of bias, (?) unclear and (-) a high risk of bias on a specific item.

\begin{tabular}{|c|c|c|c|c|c|c|c|c|c|}
\hline & 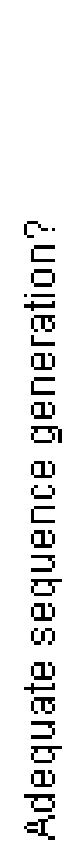 & 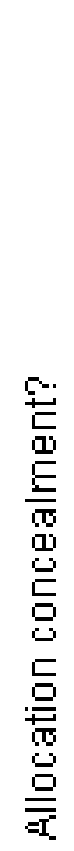 & 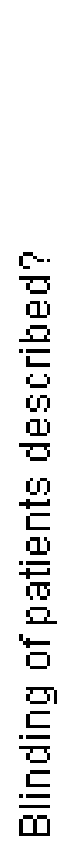 & 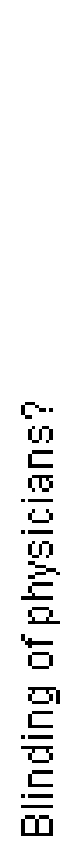 & 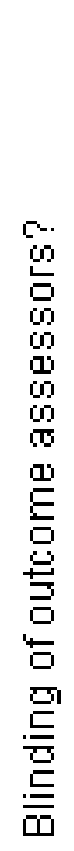 & 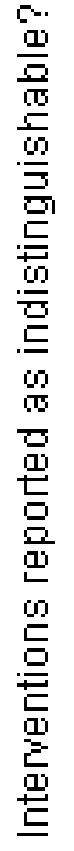 & 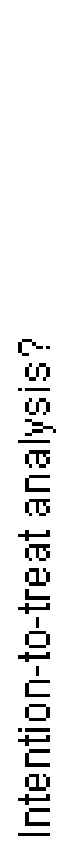 & 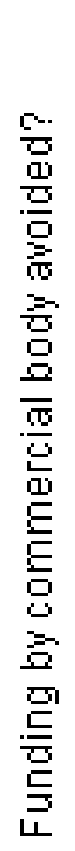 & 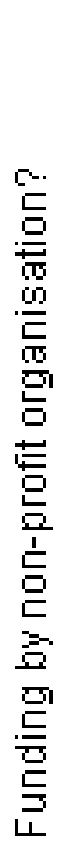 \\
\hline Brandt 2005 & $?$ & $?$ & + & + & + & + & & $?$ & + \\
\hline
\end{tabular}




\section{Effects of interventions}

See: Summary of findings for the main comparison

Data on clinical outcomes at the end of treatment were provided by the investigators in personal communications. Pain in the index knee was measured after a 50 -foot walk on a $10 \mathrm{~cm}$ visual analogue scale (VAS) (Brandt 2005). The analysis revealed a difference in means between doxycycline and placebo of $-0.20 \mathrm{~cm}(95 \% \mathrm{CI}-$ 0.77 to $0.37 \mathrm{~cm}, \mathrm{P}=0.49$, Figure 3 ). The Likert version of the WOMAC function subscale was used to measure disability after 30 months (range 17 to 85 ), with a mean difference of -1.10 (95\% CI -3.86 to $1.66, \mathrm{P}=0.44$, Figure 4). These differences correspond to clinically irrelevant effect sizes of -0.08 and -0.09 standard deviation units for pain and function, respectively. The difference in changes in minimum joint space narrowing was in favour of doxycycline $(-0.15 \mathrm{~mm}, 95 \%$ CI -0.28 to $-0.02 \mathrm{~mm}, \mathrm{P}$ $=0.03$, Figure 5 ), which corresponds to a small effect size of -0.23 standard deviation units.

Figure 3. Forest plot of I trial comparing the effects of doxycycline and placebo on knee pain. Values on $x$ axis denote mean differences in 50-foot walking pain as measured on a 10 -cm VAS scale.

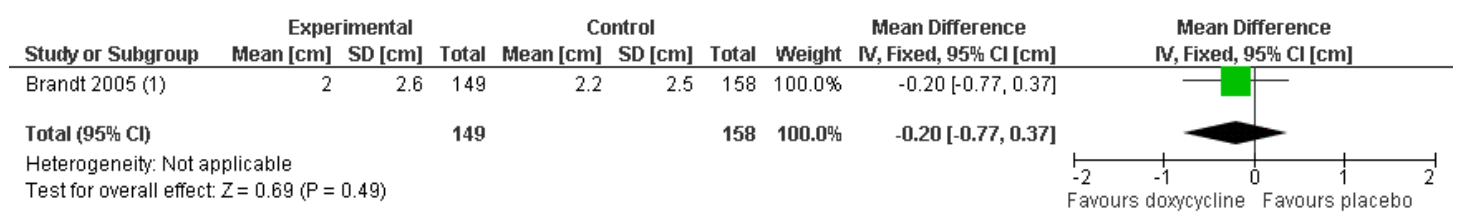

(1) Unpublished data provided by investigators in personal communication.

Figure 4. Forest plot of I trial comparing the effects of doxycycline and placebo on physical function. Values on $\mathrm{x}$-axis denote mean differences in WOMAC disability scores.

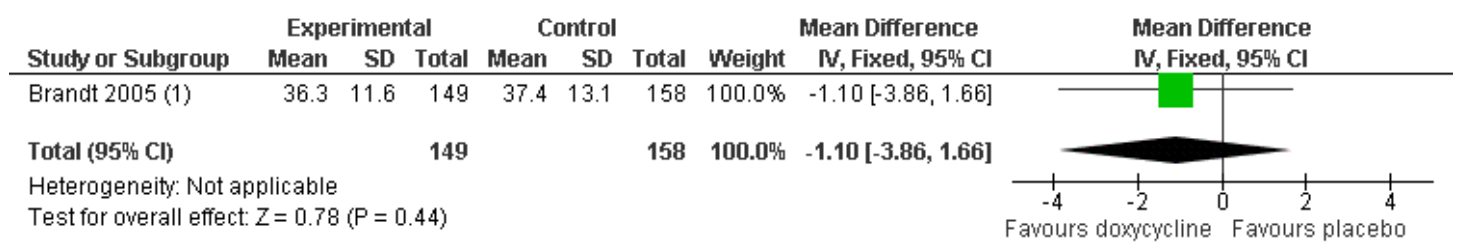

(1) Unpublished data provided by investigators in personal communication. 
Figure 5. Forest plot of I trial comparing the effects of doxycycline and placebo on physical function. Values on $\mathrm{x}$-axis denote mean differences in minimum joint space width in $\mathrm{mm}$.

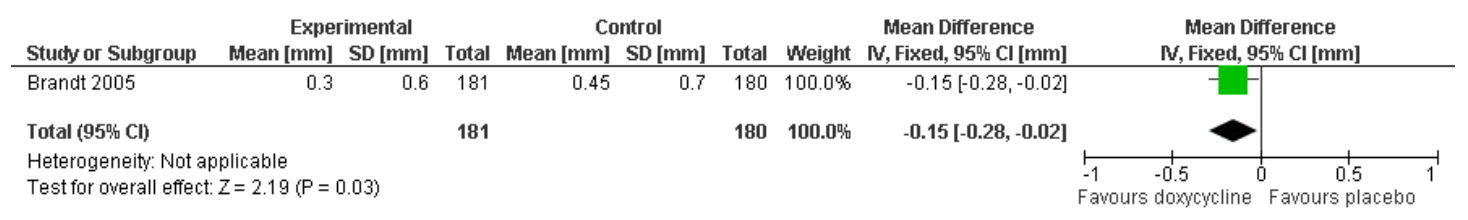


During the 30 months of treatment, patients were more likely to withdraw due to adverse events in the doxycycline group compared to the placebo group (RR 1.69, 95\% CI 1.03 to $2.75, \mathrm{P}=$ 0.04 , Figure 6 ). Data on serious adverse events were provided by investigators in personal communications. The authors found 31 patients with serious adverse events in the doxycyline group and 29 in the placebo group (RR 1.04, 95\% CI 0.65 to $1.67, \mathrm{P}=0.86$, Figure 7). None of these events were fatal and none of the serious adverse events were deemed to be related to doxycycline (Brandt 2005).

Figure 6. Forest plot of I trial comparing patients withdrawn or dropped out because of adverse events between doxycycline and placebo. Values on x-axis denote risk ratios.

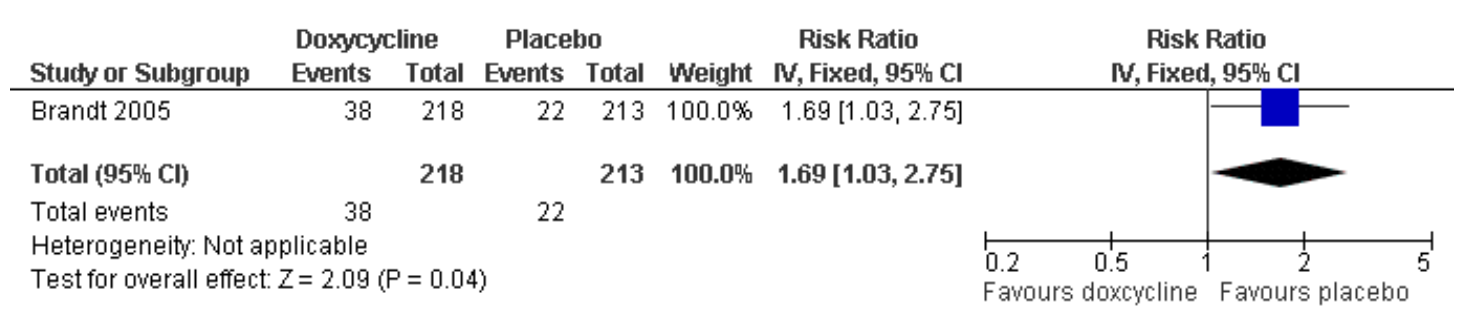

Figure 7. Forest plot of I trial comparing patients experiencing any serious adverse event between doxycycline and placebo. Values on $\mathbf{x}$-axis denote risk ratios.

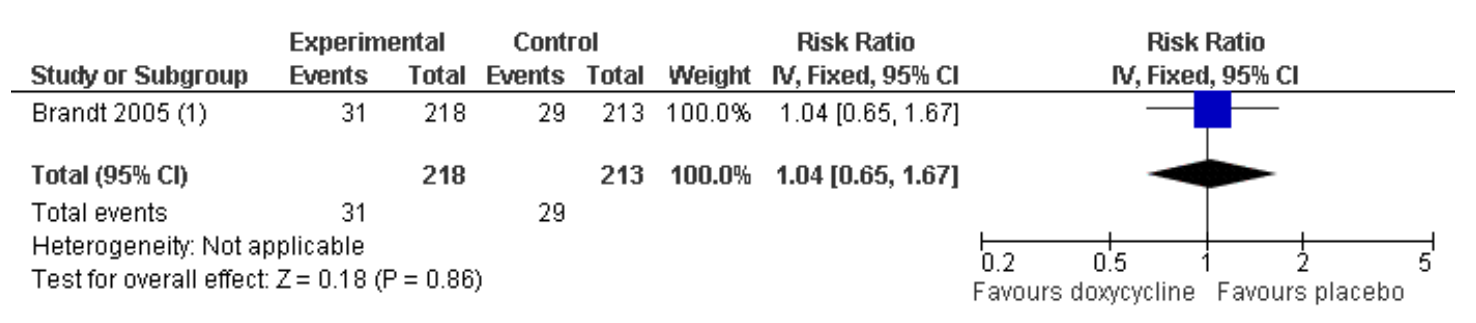

(1) Unpublished data provided by investigators in personal communication.

\section{DISCUSSION}

\section{Summary of main results}

Our systematic review indicates that the symptomatic benefit of doxycycline in patients with osteoarthritis of the knee is minimal to non-existent. The small benefit in terms of joint space narrowing is of questionable clinical relevance. The higher risk of drop-outs due to adverse events in the doxycycline group compared to placebo indicates that this benefit is outweighed by safety problems.

\section{Quality of the evidence}

The evidence is based on a single available randomised trial including only obese women with mild to moderate osteoarthritis of the knee (Brandt 2005). The trial was designed to detect differences in joint space narrowing rather than differences in clinical outcomes. No threshold for the level of knee pain was used for inclusion and the average level of knee pain was low at baseline, leaving little room for improvement. Radiological and clinical outcomes correlate poorly in patients with osteoarthritis and it is not surprising that effects of doxycycline differ for these outcomes. Joint space width in millimetres evaluated on radiographs is currently considered to be the preferred technique to evaluate structural progression in osteoarthritis, and is required by the regulatory agencies (Hellio 2009). The use of semiflexed radiographs instead of AP views improves detection of tibiofemoral joint space narrowing, 
especially in early osteoarthritis (Merle-Vincent 2007). However, there is a debate about how to define relevant radiographic progression, and a recently published OARSI-OMERACT initiative recommends dichotomising the continuous variable of joint space narrowing to distinguish between progressors and non-progressors, based on the absolute change in joint space width over a predefined threshold (Ornetti 2009). Mazzuca et al. reported that doxycycline did not differ from placebo in the frequency of relevant joint space loss using a range of different cut-offs to distinguish between the presence or absence of relevant joint space loss ( $\geq 0.5 \mathrm{~mm}, \geq 1.0 \mathrm{~mm}, \geq 20 \%$, or $\geq 50 \%$ of joint space width at baseline, Mazzuca 2006). No evidence is available for patients representing a broader spectrum of osteoarthritis, including males, patients with hip osteoarthritis and non-obese patients. The available trial is potentially biased: it remains unclear whether sequence generation and allocation concealment were adequate and a high number of patients were excluded from analyses, which may result in overestimation of benefits (Nuesch 2009).

\section{Potential biases in the review process}

We based our review on a broad literature search and it seems unlikely that we missed relevant trials (Egger 2003). Two review authors performed selection of trials and data extraction independently to minimise bias and transcription errors (Egger 2001; Gøtzsche 2007). As with any systematic review, our study is limited by the quality of the available evidence. As indicated above, only one trial was available and this trial suffered from some methodological shortcomings. Therefore, this systematic review is inconclusive (Nuesch 2009a). The observed effects, both beneficial and harmful, would need to be confirmed in at least one independent, methodologically sound trial in a wider spectrum of patients with symptomatic osteoarthritis before definite conclusions can be drawn.

\section{Agreements and disagreements with other studies or reviews}

Doxycycline may reduce the progression of cartilage degeneration in canine osteoarthritis through inhibition of cartilage matrix metallo-proteinases (Brandt 1995; Yu 1992). Similar results were ob- tained in guinea pigs (Greenwald 1994) and rabbits (Golub 1993). In a canine osteoarthritis model, doxycycline reduced disease progression (Yu 1992). This notion supports the observed reduction in joint space narrowing in the randomised trial in humans (Brandt 2005). When studied in patients with chronic seronegative arthritis (Smieja 2001), doxycyline had no effect on pain reduction or function improvement compared to placebo after three months of treatment. The trial included in our review included patients with non-inflammatory symptomatic osteoarthritis and used a longer treatment duration of 30 months, but results were similar (Brandt 2005).

\section{A U THORS'CONCLUSIONS}

\section{Implications for practice}

The symptomatic benefit of doxycycline is minimal to non-existent, while the small benefit in terms of joint space narrowing is of questionable clinical relevance and outweighed by safety problems. Doxycycline should therefore not be recommended for the treatment of osteoarthritis of the knee or hip.

\section{Implications for research}

The available evidence of the effectiveness of doxycycline is based on a single randomised trial. An additional placebo-controlled trial would be needed before firm conclusions can be drawn. This trial should be appropriately powered, use adequate mechanisms to conceal allocation and include all patients in the analyses according to the intention-to-treat principle. The trial should include a broad spectrum of patients, including males and non-obese individuals.

\section{ACKNOWLEDGEMENTS}

We thank the Cochrane Musculoskeletal Group editorial team for valuable comments and Malcolm Sturdy for database support. The authors are grateful to Kenneth Brandt and Steve Mazzuca for providing unpublished data from their trial. 


\section{R E F E R E N C E S}

\section{References to studies included in this review}

\section{Brandt 2005 \{published and unpublished data\}}

Brandt KD, Mazzuca SA. Experience with a placebo-controlled randomized clinical trial of a disease-modifying drug for osteoarthritis: the doxycycline trial. Rheumatic Diseases Clinics of North America 2006;32(1):217-34, xi-xii.

* Brandt KD, Mazzuca SA, Katz BP, Lane KA, Buckwalter KA, Yocum $\mathrm{DE}$, et al.Effects of doxycycline on progression of osteoarthritis: results of a randomized, placebo-controlled, double-blind trial. Arthritis and Rheumatism 2005;52(7):2015-25.

Hellio Le Graverand MP, Brandt KD, Mazzuca SA, Katz BP, Buck R, Lane KA, et al.Association between concentrations of urinary type II collagen neoepitope (uTIINE) and joint space narrowing in patients with knee osteoarthritis. Osteoarthritis Cartilage 2006;14(11):118995.

Mazzuca SA, Brandt KD, Katz BP, Lane KA, Bradley JD, Heck LW, et al.Subject retention and adherence in a randomized placebo-controlled trial of a disease-modifying osteoarthritis drug. Arthritis and Rheumatism 2004;51(6):933-40.

Mazzuca SA, Brandt KD, Katz BP, Lane KA, Buckwalter KA Comparison of quantitative and semiquantitative indicators of joint space narrowing in subjects with knee osteoarthritis. Annals of the Rheumatic Diseases 2006;65(1):64-8.

Mazzuca SA, Brandt KD, Schauwecker DS, Katz BP, Meyer JM, Lane KA, et al.Severity of joint pain and Kellgren-Lawrence grade at baseline are better predictors of joint space narrowing than bone scintigraphy in obese women with knee osteoarthritis. Journal of Rheumatology 2005;32(8):1540-6.

\section{References to studies excluded from this review}

\section{Brandt 1995 \{published data only\}}

Brandt KD. Modification by oral doxycycline administration of articular cartilage breakdown in osteoarthritis. Journal of Rheumatology 1995;22(SUPPL. 43):149-51.

\section{Smieja 2001 \{published data only\}}

Smieja M, MacPherson DW, Kean W, Schmuck ML, Goldsmith $\mathrm{CH}$, Buchanan W, et al.Randomised, blinded, placebo controlled trial of doxycycline for chronic seronegative arthritis. Annals of the Rheumatic Diseases 2001;60(12):1088-94.

\section{Additional references}

\section{Altman 1996}

Altman R, Brandt K, Hochberg M, Moskowitz R, Bellamy N, Bloch DA, et al.Design and conduct of clinical trials in patients with osteoarthritis: recommendations from a task force of the Osteoarthritis Research Society. Results from a workshop. Osteoarthritis Cartilage 1996;4(4):217-43.

Buckland-Wright 1995

Buckland-Wright JC, Macfarlane DG, Williams SA, Ward RJ. Accuracy and precision of joint space width measurements in standard and macroradiographs of osteoarthritic knees. Annals of the Rheumatic Diseases 1995;54(11):872-80.
Cohen 1988

Cohen J. Statistical power analysis for the behavioral sciences. 2nd Edition. Hillsdale, NJ: Lawrence Earlbaum Associates, 1988.

\section{Dickersin 1994}

Dickersin K, Scherer R, Lefebvre C. Identifying relevant studies for systematic reviews. BMJ 1994;309(6964):1286-91.

\section{Dieppe 2005}

Dieppe P. Disease modification in osteoarthritis: are drugs the answer?. Arthritis and Rheumatism 2005;52(7):1956-9.

\section{Egger 2001}

Egger M, Smith GD. Principles of and procedures for systematic reviews. In: Egger M, Smith GD, Altman DG editor(s). Systematic Reviews in Health Care: Meta-Analyis in Context. London: BMJ Books, 2001:23-42.

Egger 2003

Egger M, Juni P, Bartlett C, Holenstein F, Sterne J. How important are comprehensive literature searches and the assessment of trial quality in systematic reviews? Empirical study. Health technology assessment (Winchester, England) 2003;7(1):1-76.

\section{Golub 1993}

Golub LM, Ramamurthy NS, McNamara TF, et al.Method to reduce connective tissue destruction. US Patent 5258371 November 3, 1993.

\section{Greenwald 1994}

Greenwald RA. Treatment of destructive arthritis disorders with MMP inhibitors. Annals of the New York Academy of Sciences 1994; 731:181-98.

\section{Guyatt 2008}

Guyatt G, Oxman AD, Vist GE, Kunz R, Falck-Ytter Y, Schunemann HJ. GRADE: what is "quality of evidence" and why is it important to clinicians?. BMJ 2008;336:995-8.

\section{Gøtzsche 2007}

Gøtzsche PC, Hróbjartsson A, Maric K, Tendal B. Data extraction errors in meta-analyses that use standardized mean differences. JAMA 2007;298(4):430-7.

\section{Hellio 2009}

Hellio Le Graverand-Gastineau MP. OA clinical trials: current targets and trials for OA. Choosing molecular targets: what have we learned and where we are headed?. Osteoarthritis Cartilage 2009; in press.

\section{Higgins 2008}

Higgins JPT, Green S (editors). Cochrane Handbook for Systematic Reviews of Interventions Version 5.0.1 [updated September 2008]. The Cochrane Collaboration, 2008. Available from www.cochranehandbook.org. The Cochrane Collaboration.

\section{Juni 2001}

Juni P, Altman DG, Egger M. Systematic reviews in health care: assessing the quality of controlled clinical trials. BMJ 2001;323 (7303):42-6.

Juni 2006

Juni P, Reichenbach S, Dieppe P. Osteoarthritis: rational approach to treating the individual. Best Practice and Research. Clinical Rheumatology 2006;20(4):721-40. 


\section{Lequesne 1995}

Lequesne M. Quantitative measurements of joint space during progression of osteoarthritis: chondrometry. In: Kuettner K, Goldberg V editor(s). Osteoarthritic disorders. Rosemont (IL): American Academy of Orthopaedic Surgeons, 1995:427-44.

\section{Mazzuca 2006}

Mazzuca SA, Brandt KD, Katz BP, Lane KA, Buckwalter KA. Comparison of quantitative and semiquantitative indicators of joint space narrowing in subjects with knee osteoarthritis. Annals of the Rheumatic Diseases 2006;65(1):64-8.

\section{Merle-Vincent 2007}

Merle-Vincent F, Vignon E, Brandt K, Piperno M, Coury-Lucas F, Conrozier T, et al.Superiority of the Lyon schuss view over the standing anteroposterior view for detecting joint space narrowing, especially in the lateral tibiofemoral compartment, in early knee osteoarthritis. Annals of the Rheumatic Diseases 2007;66(6):747-53.

\section{Nuesch 2009}

Nuesch E, Trelle S, Reichenbach S, Rutjes AWS, Burgi E, Scherer M, Altman DG, Juni P. The effects of the exclusion of patients from the analysis in randomised controlled trials: meta-epidemiological study. BMJ (in press).

\section{Nuesch 2009a}

Nuesch E, Juni P. Commentary: which meta-analyses are conclusive?. International Journal of Epidemiology 2009;38(1):298-303.

\section{Ornetti 2009}

Ornetti P, Brandt K, Hellio-Le Graverand MP, Hochberg M, Hunter DJ, Kloppenburg M, et al.OARSI-OMERACT definition of relevant radiological progression in hip/knee osteoarthritis. Osteoarthritis Cartilage 2009;17(7):842-9.

\section{Pham 2004}

Pham T, van der Heijde D, Altman RD, Anderson JJ, Bellamy N, Hochberg M, et al.OMERACT-OARSI initiative: Osteoarthritis Research Society International set of responder criteria for osteoarthritis clinical trials revisited. Osteoarthritis Cartilage 2004;12(5):389-99.

\section{Reichenbach 2007}

Reichenbach S, Sterchi R, Scherer M, Trelle S, Burgi E, Burgi U, et al.Meta-analysis: chondroitin for osteoarthritis of the knee or hip. Annals of Internal Medicine 2007;146(8):580-90.

\section{RevMan 2008}

The Nordic Cochrane Centre. The Cochrane Collaboration. Review Manager (RevMan). 5.0. Copenhagen: The Nordic Cochrane Centre. The Cochrane Collaboration, 2008.

\section{Rubin 2000}

Rubin BK, Tamaoki J. Macrolide antibiotics as biological response modifiers. Current Opinion in Investigational Drugs 2000;1(2):16972 .

\section{Shlopov 1999}

Shlopov BV, Smith GN Jr, Cole AA, Hasty KA. Differential patterns of response to doxycycline and transforming growth factor beta1 in the down-regulation of collagenases in osteoarthritic and normal human chondrocytes. Arthritis and Rheumatism 1999;42(4):71927.

\section{Smith 1996}

Smith GN Jr, Brandt KD, Hasty KA. Activation of recombinant human neutrophil procollagenase in the presence of doxycycline results in fragmentation of the enzyme and loss of enzyme activity. Arthritis and Rheumatism 1996;39(2):235-44.

\section{Vlad 2007}

Vlad SC, LaValley MP, McAlindon TE, Felson DT. Glucosamine for pain in osteoarthritis: why do trial results differ?. Arthritis and Rheumatism 2007;56(7):2267-77.

\section{Yu 1992}

Yu LP Jr, Smith GN Jr, Brandt KD, Myers SL, O'Connor BL, Brandt DA. Reduction of the severity of canine osteoarthritis by prophylactic treatment with oral doxycycline. Arthritis and Rheumatism 1992;35 (10):1150-9.

* Indicates the major publication for the study 


\section{CHARACTERISTICS OF STUDIES}

\section{Characteristics of included studies [ordered by study ID]}

Brandt 2005

\begin{tabular}{l|l}
\hline Methods & $\begin{array}{l}\text { Randomised controlled trial with } 2 \text { parallel groups } \\
\text { Randomisation stratified by centre } \\
\text { Trial duration: } 30 \text { months } \\
\text { Multicentre trial including } 6 \text { centres } \\
\text { No power calculation reported }\end{array}$ \\
\hline Participants & $\begin{array}{l}431 \text { patients with radiologically confirmed knee osteoarthritis were randomised } \\
\text { Number of females: } 431(100 \%)\end{array}$ \\
\hline $\begin{array}{l}\text { Average age: } 54.9 \text { years } \\
\text { Average BMI: } 36.7 \mathrm{~kg} / \mathrm{m}^{2} \\
\text { Severity of knee osteoarthritis: } 59 \% \text { with Kellgren/Lawrence grade } 2 \text { and } 41 \% \text { with } \\
\text { Kellgren/Lawrence grade } 3\end{array}$ \\
\hline Interventions & $\begin{array}{l}\text { Experimental intervention: doxycycline, } 100 \text { mg twice daily } \\
\text { Control intervention: placebo, twice daily } \\
\text { Treatment duration: } 30 \text { months } \\
\text { Analgesics other than study drugs allowed and intake was similar between groups }\end{array}$ \\
\hline Outcomes & $\begin{array}{l}\text { Extracted pain outcome: } 50 \text {-foot walking pain after } 30 \text { months } \\
\text { Extracted function outcome: WOMAC disability subscore after } 30 \text { months } \\
\text { Primary outcome: joint space narrowing in the tibiofemoral compartment }\end{array}$ \\
\hline Notes & - \\
\hline
\end{tabular}

Risk of bias

\begin{tabular}{l|l|l}
\hline Item & Authors' judgement & Description \\
\hline Adequate sequence generation? & Unclear & $\begin{array}{l}\text { Quote: "Subjects (...) were randomly assigned” } \\
\text { Comment: no mention of the mechanism used for sequence } \\
\text { generation }\end{array}$ \\
\hline Allocation concealment? & Unclear & $\begin{array}{l}\text { Quote: "Patients were allocated randomly to treatment groups } \\
\text { in blocks of 6" } \\
\text { Comment: no mention of concealment of allocation }\end{array}$ \\
\hline Blinding of patients described? & Yes & $\begin{array}{l}\text { Comment: indistinguishable interventions and the description } \\
\text { of a double-blind phase implies blinding of patients }\end{array}$ \\
\hline Blinding of physicians? & Yes & $\begin{array}{l}\text { Comment: clearly distinguished between single blind run-in pe- } \\
\text { riod and double-blind phase. Blinding of physicians probable }\end{array}$
\end{tabular}


Brandt 2005 (Continued)

\begin{tabular}{|c|c|c|}
\hline Blinding of outcome assessors? & Yes & $\begin{array}{l}\text { Comment: depending on the outcome, patients or physicians } \\
\text { were the assessors, both of which were blinded }\end{array}$ \\
\hline $\begin{array}{l}\text { Interventions reported as indistinguish- } \\
\text { able? }\end{array}$ & Yes & Quote: "matched placebo" \\
\hline $\begin{array}{l}\text { Intention-to-treat analysis? } \\
\text { All outcomes }\end{array}$ & No & $\begin{array}{l}69 \text { of } 218 \text { patients }(32 \%) \text { excluded in experimental group and } \\
55 \text { of } 213 \text { patients }(26 \%) \text { excluded in control group }\end{array}$ \\
\hline Funding by commercial body avoided? & Unclear & No information provided \\
\hline Funding by non-profit organisation? & Yes & $\begin{array}{l}\text { Quote: "Supported by the NIH (grants R01-AR-43348, P60- } \\
\text { AR-20582, and R01-AR-44370)" }\end{array}$ \\
\hline
\end{tabular}

$\mathrm{BMI}=$ body mass index

Characteristics of excluded studies [ordered by year of study]

\begin{tabular}{ll} 
Brandt 1995 & Animal study \\
\hline Smieja 2001 & No patients in osteoarthritis
\end{tabular}

Doxycycline for osteoarthritis of the knee or hip (Review)

Copyright (־ 2009 The Cochrane Collaboration. Published by John Wiley \& Sons, Ltd. 
DATA AND ANALYSES

Comparison 1. Doxycycline versus placebo

\begin{tabular}{|c|c|c|c|c|}
\hline Outcome or subgroup title & $\begin{array}{l}\text { No. of } \\
\text { studies }\end{array}$ & $\begin{array}{c}\text { No. of } \\
\text { participants }\end{array}$ & Statistical method & Effect size \\
\hline 1 Pain & 1 & 307 & Mean Difference (IV, Fixed, 95\% CI) & $-0.20[-0.77,0.37]$ \\
\hline 2 Physical function & 1 & 307 & Mean Difference (IV, Fixed, 95\% CI) & $-1.10[-3.86,1.66]$ \\
\hline 3 Minimum joint space width & 1 & 361 & Mean Difference (IV, Fixed, 95\% CI) & $-0.15[-0.28,-0.02]$ \\
\hline $\begin{array}{l}4 \text { Number of patients withdrawn } \\
\text { due to adverse events }\end{array}$ & 1 & 431 & Risk Ratio (IV, Fixed, 95\% CI) & $1.69[1.03,2.75]$ \\
\hline $\begin{array}{l}5 \text { Number of patients experiencing } \\
\text { any serious adverse events }\end{array}$ & 1 & 431 & Risk Ratio (IV, Fixed, 95\% CI) & $1.04[0.65,1.67]$ \\
\hline
\end{tabular}

Analysis I.I. Comparison I Doxycycline versus placebo, Outcome I Pain.

Review: Doxycycline for osteoarthritis of the knee or hip

Comparison: I Doxycycline versus placebo

Outcome: I Pain

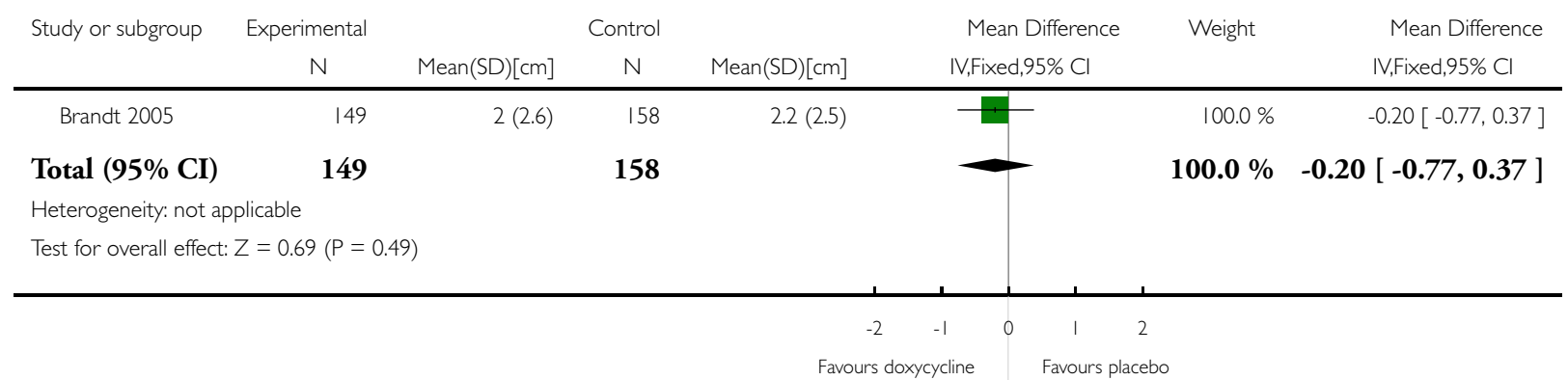




\section{Analysis I.2. Comparison I Doxycycline versus placebo, Outcome 2 Physical function.}

Review: Doxycycline for osteoarthritis of the knee or hip

Comparison: I Doxycycline versus placebo

Outcome: 2 Physical function

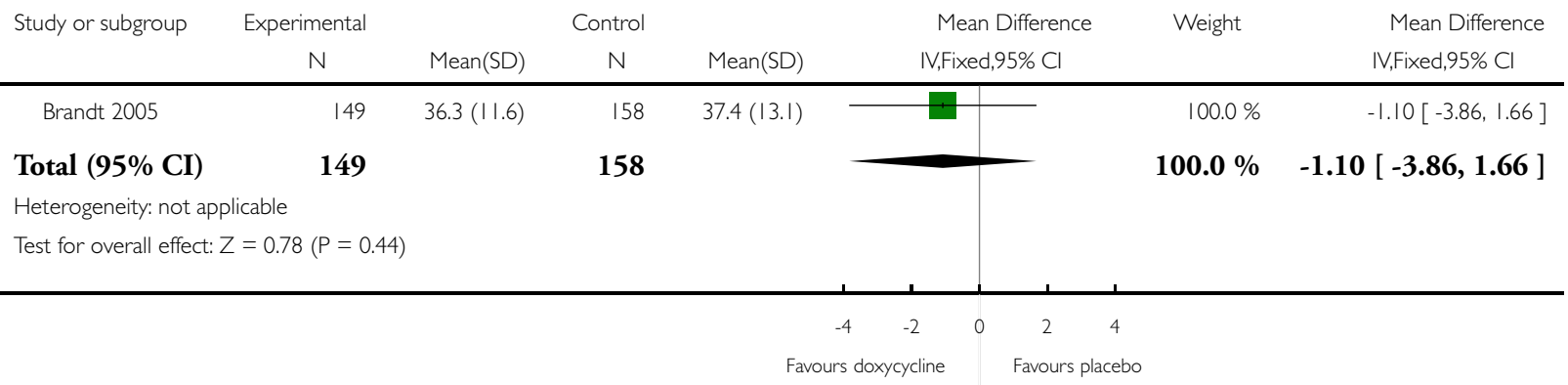

Analysis I.3. Comparison I Doxycycline versus placebo, Outcome 3 Minimum joint space width.

Review: Doxycycline for osteoarthritis of the knee or hip

Comparison: I Doxycycline versus placebo

Outcome: 3 Minimum joint space width

\begin{tabular}{|c|c|c|c|c|c|c|c|}
\hline \multirow[t]{2}{*}{ Study or subgroup } & \multirow{2}{*}{$\begin{array}{c}\text { Experimental } \\
\mathrm{N}\end{array}$} & \multicolumn{3}{|c|}{ Control } & \multirow{2}{*}{$\begin{array}{l}\text { Mean Difference } \\
\text { IV,Fixed,95\% Cl }\end{array}$} & \multirow[t]{2}{*}{ Weight } & \multirow{2}{*}{$\begin{array}{l}\text { Mean Difference } \\
\text { IV,Fixed,95\% Cl }\end{array}$} \\
\hline & & Mean(SD) $[\mathrm{mm}]$ & $\mathrm{N}$ & Mean(SD) $[\mathrm{mm}]$ & & & \\
\hline Brandt 2005 & 181 & $0.3(0.6)$ & 180 & $0.45(0.7)$ & & $100.0 \%$ & $-0.15[-0.28,-0.02]$ \\
\hline Total (95\% CI) & 181 & & 180 & & - & $100.0 \%$ & $-0.15[-0.28,-0.02]$ \\
\hline
\end{tabular}

Heterogeneity: not applicable

Test for overall effect: $Z=2.19(P=0.029)$

\begin{tabular}{|c|c|c|}
\hline-1 & -0.5 & 0 \\
\hline
\end{tabular}


Analysis I.4. Comparison I Doxycycline versus placebo, Outcome 4 Number of patients withdrawn due to adverse events.

Review: Doxycycline for osteoarthritis of the knee or hip

Comparison: I Doxycycline versus placebo

Outcome: 4 Number of patients withdrawn due to adverse events

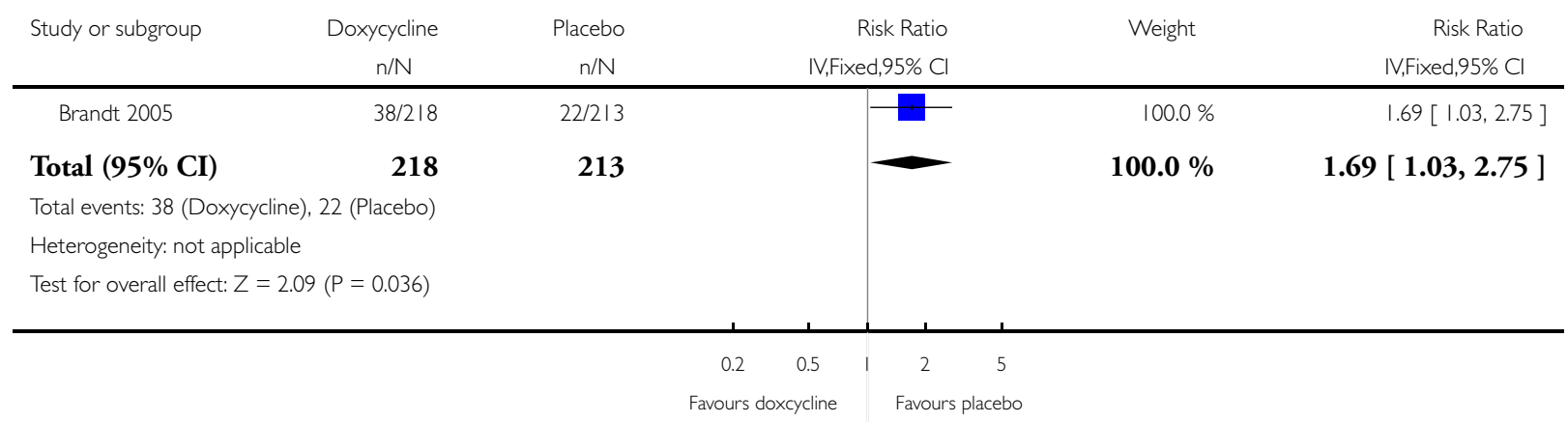

Analysis I.5. Comparison I Doxycycline versus placebo, Outcome 5 Number of patients experiencing any serious adverse events.

Review: Doxycycline for osteoarthritis of the knee or hip

Comparison: I Doxycycline versus placebo

Outcome: 5 Number of patients experiencing any serious adverse events

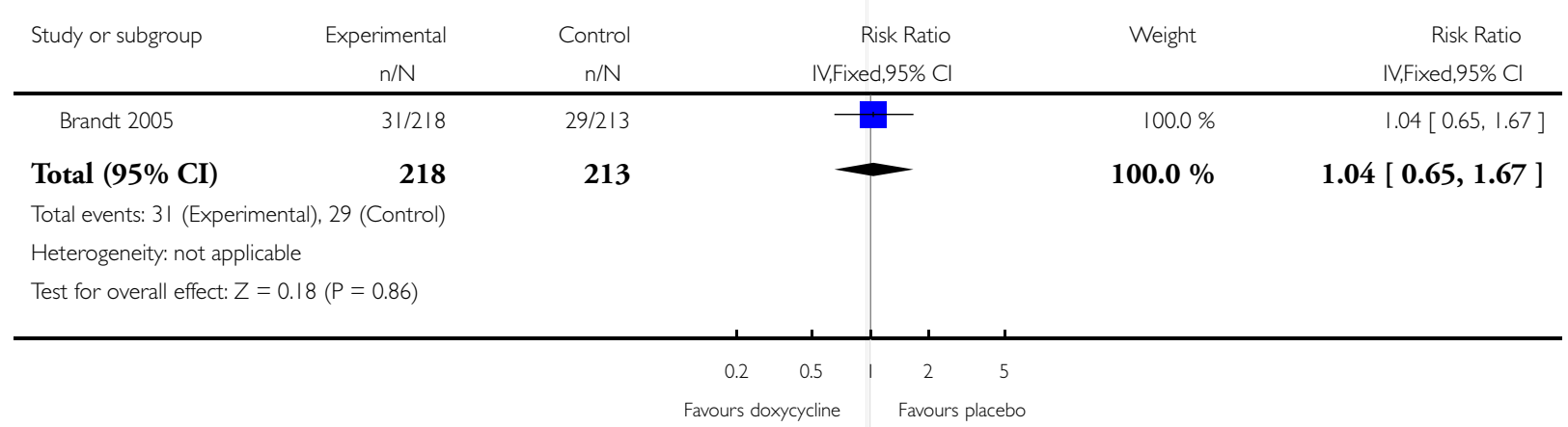




\section{A P P E N D I CES}

Appendix I. MEDLINE, EMBASE and CINAHL search strategy

\begin{tabular}{|c|c|c|}
\hline OVID MEDLINE & OVID EMBASE & CINAHL through EBSCOhost \\
\hline $\begin{array}{l}\text { Search terms for design } \\
\text { 1. randomized controlled trial.pt. } \\
\text { 2. controlled clinical trial.pt. } \\
\text { 3. randomized controlled trial.sh. } \\
\text { 4. random allocation.sh. } \\
\text { 5. double blind method.sh. } \\
\text { 6. single blind method.sh. } \\
\text { 7. clinical trial.pt. } \\
\text { 8. exp clinical trial/ } \\
\text { 9. (clin } \$ \text { adj } 25 \text { trial } \$ \text { ).ti,ab. } \\
\text { 10. ((singl\$ or doubl\$ or trebl\$ or tripl\$) } \\
\text { adj25 (blind } \$ \text { or mask } \$) \text { ).ti,ab. } \\
\text { 11. placebos.sh. } \\
\text { 12. placebo } \$ . t i, a b . \\
\text { 13. random\$.ti,ab. } \\
\text { 14. research design.sh. } \\
\text { 15. comparative study.sh. } \\
\text { 16. exp evaluation studies/ } \\
\text { 17. follow up studies.sh. } \\
\text { 18. prospective studies.sh. } \\
\text { 19. (control } \$ \text { or prospectiv } \$ \text { or volun- } \\
\text { teer } \$ \text { ).ti,ab. }\end{array}$ & $\begin{array}{l}\text { Search terms for design } \\
\text { 1. randomized controlled trial.sh. } \\
\text { 2. randomization.sh. } \\
\text { 3. double blind procedure.sh. } \\
\text { 4. single blind procedure.sh. } \\
\text { 5. exp clinical trials/ } \\
\text { 6. (clin } \$ \text { adj } 25 \text { trial\$).ti,ab. } \\
\text { 7. ((singl\$ or doubl\$ or trebl\$ or tripl\$) } \\
\text { adj25 (blind } \$ \text { or mask\$)).ti,ab. } \\
\text { 8. placebo.sh. } \\
\text { 9. placebo } \$ . t i, a b . \\
\text { 10. random\$.ti,ab. } \\
\text { 11. methodology.sh. } \\
\text { 12. comparative study.sh. } \\
\text { 13. exp evaluation studies/ } \\
\text { 14. follow up.sh. } \\
\text { 15. prospective study.sh. } \\
\text { 16. (control\$ or prospectiv\$ or volun- } \\
\text { teer\$).ti,ab. }\end{array}$ & 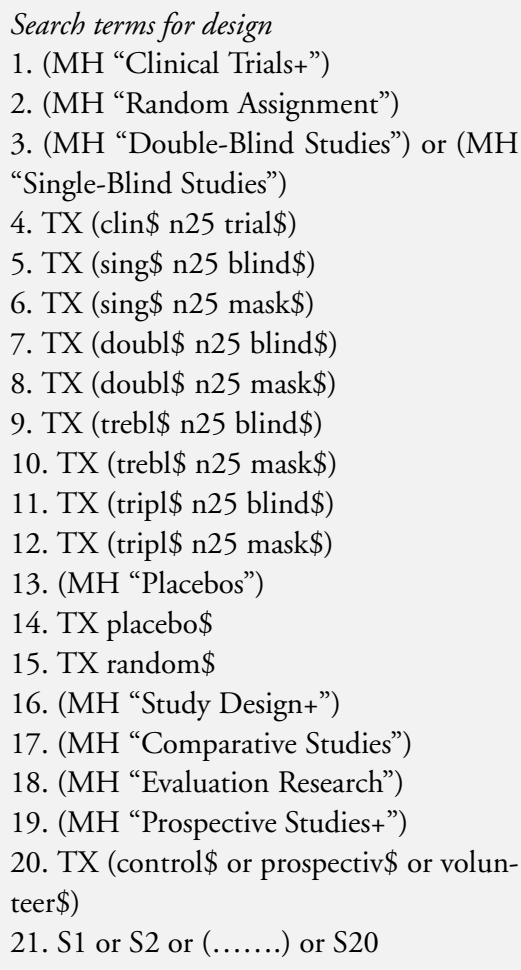 \\
\hline $\begin{array}{l}\text { Search terms for Osteoarthritis } \\
\text { 20. exp osteoarthritis/ } \\
\text { 21. osteoarthriti\$.ti,ab,sh. } \\
\text { 22. osteoarthro\$.ti,ab,sh. } \\
\text { 23. gonarthriti\$.ti,ab,sh. } \\
\text { 24. gonarthro\$.ti,ab,sh. } \\
\text { 25. coxarthriti } \$ . t i, a b, s h . \\
\text { 26. coxarthro\$.ti,ab,sh. } \\
\text { 27. arthros\$.ti,ab. } \\
\text { 28. arthrot\$.ti,ab. } \\
\text { 29. ((knee\$ or hip\$ or joint\$) adj3 (pain\$ } \\
\text { or ach\$ or discomfort\$)).ti,ab. } \\
\text { 30. ((knee\$ or hip\$ or joint\$) adj3 } \\
\text { stiff\$).ti,ab. }\end{array}$ & $\begin{array}{l}\text { Search terms for Osteoarthritis } \\
\text { 17. exp osteoarthritis/ } \\
\text { 18. osteoarthriti } \$ . t i, a b, s h . \\
\text { 19. osteoarthro\$.ti,ab,sh. } \\
\text { 20. gonarthriti } \$ . t i, a b, s h . \\
\text { 21. gonarthro\$.ti,ab,sh. } \\
\text { 22. coxarthriti\$.ti,ab,sh. } \\
\text { 23. coxarthro\$.ti,ab,sh. } \\
\text { 24. arthros\$.ti,ab. } \\
\text { 25. arthrot\$.ti,ab. } \\
\text { 26. ( (knee\$ or hip\$ or joint\$) adj3 (pain\$ } \\
\text { or ach\$ or discomfort\$)).ti,ab. } \\
\text { 27. ((knee\$ or hip\$ or joint } \$) \text { adj3 } \\
\text { stiff\$).ti,ab. }\end{array}$ & $\begin{array}{l}\text { Search terms for Osteoarthritis } \\
\text { 22. osteoarthriti\$ } \\
\text { 23. (MH “Osteoarthritis") } \\
\text { 24. TX osteoarthro\$ } \\
\text { 25. TX gonarthriti\$ } \\
\text { 26. TX gonarthro\$ } \\
\text { 27. TX coxarthriti\$ } \\
\text { 28. TX coxarthro\$ } \\
\text { 29. TX arthros\$ } \\
\text { 30. TX arthrot\$ } \\
\text { 31. TX knee\$ n3 pain\$ } \\
\text { 32. TX hip\$ n3 pain\$ } \\
\text { 33. TX joint\$ n3 pain\$ } \\
\text { 34. TX knee\$ n3 ach\$ } \\
\text { 35. TX hip\$ n3 ach\$ } \\
\text { 36. TX joint\$ n3 ach\$ }\end{array}$ \\
\hline
\end{tabular}




\begin{tabular}{|c|c|c|}
\hline & & $\begin{array}{l}\text { 37. TX knee } \$ \mathrm{n} 3 \text { discomfort } \$ \\
\text { 38. TX hip } \$ \mathrm{n} 3 \text { discomfort } \$ \\
\text { 39. TX joint } \$ \mathrm{n} 3 \text { discomfort } \$ \\
\text { 40. TX knee } \$ \mathrm{n} 3 \text { stiff } \$ \\
\text { 41. TX hip } \$ \mathrm{n} 3 \text { stiff } \$ \\
\text { 42. TX joint } \$ \mathrm{n} 3 \text { stiff } \$ \\
\text { 43. } S 22 \text { or } S 23 \text { or } S 24 \ldots \text { or } \$ 42\end{array}$ \\
\hline $\begin{array}{l}\text { Search terms for Doxycycline } \\
\text { 31. exp doxycycline/ } \\
\text { 32. doxycycline.tw. } \\
\text { 33. deoxyoxytetracycline.tw. } \\
\text { 34. hydramycin.tw. } \\
\text { 35. vibramycin.tw. } \\
\text { 36. vibravenos.tw. } \\
\text { 37. oracea.tw. } \\
\text { 38. adoxa.tw. } \\
\text { 39. doryx.tw. } \\
\text { 40. doxy.tw. } \\
\text { 41. monodox\$.tw. } \\
\text { 42. periostat.tw. } \\
\text { 43. atridox.tw. } \\
\text { 44. vibrox\$.tw. }\end{array}$ & $\begin{array}{l}\text { Search terms for Doxycycline } \\
\text { 28. exp doxycycline/ } \\
\text { 29. doxycycline.tw. } \\
\text { 30. deoxyoxytetracycline.tw. } \\
\text { 31. hydramycin.tw. } \\
\text { 32. vibramycin.tw. } \\
\text { 33. vibravenos.tw. } \\
\text { 34. oracea.tw. } \\
\text { 35. adoxa.tw. } \\
\text { 36. doryx.tw. } \\
\text { 37. doxy.tw. } \\
\text { 38. monodox\$.tw. } \\
\text { 39. periostat.tw. } \\
\text { 40. atridox.tw. } \\
\text { 41. vibrox\$.tw. }\end{array}$ & $\begin{array}{l}\text { Search terms for Doxycycline } \\
\text { 44. (MH “ Doxycycline ”) } \\
\text { 45. TX doxycycline } \\
\text { 46. TX deoxyoxytetracycline } \\
\text { 47. TX hydramycin } \\
\text { 48. TX vibramycin } \\
\text { 49. TX vibravenos } \\
\text { 50. TX oracea } \\
\text { 51. TX adoxa } \\
\text { 52. TX doryx } \\
\text { 53. TX doxy } \$ \\
\text { 54. TX monodox } \$ \\
\text { 55. TX periostat } \\
\text { 56. TX atridox } \\
\text { 57. TX vibrox } \$ \\
\text { 58. S44 or S45 or.... S57 }\end{array}$ \\
\hline $\begin{array}{l}\text { Combining terms } \\
\text { 45. or/1-19 } \\
\text { 46. or/20-30 } \\
\text { 47. or/31-44 } \\
\text { 48. and } / 45-47 \\
\text { 49. animal/ } \\
\text { 50. animal/ and human/ } \\
\text { 51. } 49 \text { not } 50 \\
\text { 52. } 48 \text { not } 51 \\
\text { 53. remove duplicates from } 52\end{array}$ & $\begin{array}{l}\text { Combining terms } \\
\text { 42. or/1-16 } \\
\text { 43. or/17-27 } \\
\text { 44. or/28-41 } \\
\text { 45. and } / 42-44 \\
\text { 46. animal/ } \\
\text { 47. animal/ and human/ } \\
\text { 48. } 46 \text { not } 47 \\
\text { 49. } 45 \text { not } 48 \\
\text { 50. remove duplicates from } 49\end{array}$ & $\begin{array}{l}\text { Combining terms } \\
\text { 59. S21 and S43 and S58 }\end{array}$ \\
\hline
\end{tabular}




\section{Appendix 2. CENTRAL search strategy}

\section{CENTRAL}

Search terms for osteoarthritis

\#1. MeSH descriptor Osteoarthritis explode all trees

\#2. (osteoarthritis* OR osteoarthro* OR gonarthriti* OR gonarthro*

OR coxarthriti* OR coxarthro* OR arthros* OR arthrot* OR

((knee* OR hip* OR joint*) near/3 (pain* OR ach* OR discomfort*))

OR ((knee* OR hip* OR joint* ${ }^{*}$ near/3 stiff*)) in Clinical Trials

Search terms for doxycycline

\#3. MeSH descriptor Doxycycline explode all trees

\#4. doxycycline in Clinical Trials

\#5. deoxyoxytetracycline in Clinical Trials

\#6. hydramycin in Clinical Trials

\#7. vibramycin in Clinical Trials

\#8. vibravenos in Clinical Trials

\#9. oracea in Clinical Trials

\#10. adoxa in Clinical Trials

\#11. doryx in Clinical Trials

\#12. doxy* in Clinical Trials

\#13. monodox* in Clinical Trials

\#14. periostat in Clinical Trials

\#15. atridox in Clinical Trials

\#16. vibrox* in Clinical Trials

Combining terms

\#17. (\#1 OR \#2)

\#18. (\#3 OR \#4 OR \#5 OR \#6 OR \#7 OR \#8 OR \#9 OR \#10

OR \#11 OR \#12 OR \#13 OR \#14 OR \#15 OR \#16)

\#19. (\#17 AND \#18) in Clinical Trials

\section{WHAT'S NEW}

Last assessed as up-to-date: 10 January 2009.

1 May 2008 Amended CMSG ID C118-R 


\section{H I S T O R Y}

Protocol first published: Issue 3, 2008

Review first published: Issue 4, 2009

\section{CONTRIBUTIONS OFAUTHORS}

Protocol completion: Nüesch, Rutjes, Trelle, Reichenbach, Jüni

Acquisition of data: Nüesch, Rutjes

Analysis and interpretation of data: Nüesch, Rutjes, Trelle, Reichenbach, Jüni

Manuscript preparation: Nüesch, Rutjes, Trelle, Reichenbach, Jüni

Statistical analysis. Nüesch, Rutjes

\section{DECLARATIONS OF INTEREST}

None.

\section{SOURCES OF SUPPORT}

\section{Internal sources}

- Institute of Social and Preventive Medicine, University or Bern, Switzerland. Intramural grants

\section{External sources}

- Swiss National Science Foundation, Switzerland.

National Research Program 53 on musculoskeletal health (grant numbers 4053-40-104762/3 and 3200-066378)

\section{DIFFERENCES BETWEEN PROTOCOL AND REVIEW}

Because only one study was included in our review, we used inverse variance fixed-effect model instead of the random-effects model of meta-analysis, and we did not perform the stratified analyses. Differences between experimental and control groups were expressed as mean differences instead of standardised mean differences due to better interpretability of the results. We could not perform stratified analyses or funnel plot evaluation to investigate whether potential variation between trials could be explained by biases affecting individual trials or by publication bias. 